\title{
CORRELATION STRUCTURE OF THE COORDINATION PREPAREDNESS OF MALE ADOLESCENTS AGED 13-14 ENGAGED IN EXTREME ACTIVITY
}

\author{
Iryna Ivanyshyn' \\ orcid-0000-0003-1765-8311 \\ Ihor Vypasniak ${ }^{2}$ \\ orcid-0000-0002-4192-1880
}

\author{
Lidia Kovalchuk ${ }^{3}$ \\ orcid-0000-0002-2973-8979 \\ Yurii Ivanyshyn ${ }^{4}$ \\ orcid - 0000-0002-6843-8573
}

${ }^{1-3}$ Vasyl Stefanyk Precarpathian National University, Ivano-Frankivsk, Ukraine
${ }^{4}$ Ivano-Frankivsk College of Physical Education,
Kyiv National University of Physical Education and Sport of Ukraine, Ivano-Frankivsk, Ukraine

correspondent author - I. Ivanyshyn: iraivan68@gmail.com

doi: $10.32626 / 2309-8082.2021-20.11-18$

Analysis of scientific works shows that in recent years, extreme sports have developed very rapidly, and scientists have interested in extreme personality phenomenon, in particular, trying to find out what drives people who engage in extreme motor activity types. The aim of the study was to identify the presence of correlations between indicators of coordination qualities and of basic mental properties and processes in adolescents aged 13-14 years, who are engaged in extreme motor activity (MA) types. Materials and methods. The study involved male adolescents aged $13-14$ years $(n=47)$ who are involved in extreme MA types. The tetrachoric correlation coefficient and the Chuprov correlation coefficient were used to determine the correlations between mental and physical components indicators, and the parametric Brave-Pearson correlation coefficient was used to establish the relations between coordination qualities indicators. Statistical processing was performed using the application package Statistics 6.0. Results. The study of coordination abilities structure of the studied contingent revealed that ability indicators to manage spatio-temporal characteristics are related to locus control indicators $(0.44)$, alertness $(-0.34)$, mechanical $(-0.34)$ and logical $(-0.32)$ memory; the ability to spatial parameters differentiation correlates with anxiety $(0.64)$, locus control $(-0.62)$, alertness $(0.35)$ and mechanical memory $(-0.31)$; the ability to differentiate temporal parameters correlates with mental properties indicators (anxiety, stress and locus control), as well as mental processes indicators: mechanical memory $(-0.47)$ and alertness $(-0.38)$; proneness to stress indicator $(-0.32)$ correlates with the ability to maintain static balance; logical memory indicator $(-0.51)$, proneness to stress $(0.35)$, locus control (0.37) and mechanical memory $(-0.37)$ correlates with the ability to maintain dynamic balance; indicators of social desirability bias (0.49), mechanical memory $(0.35)$ and locus control $(-0.32)$ correlated with the ability to general movements coordination. Conclusions. The integrated coordination abilities indicator is presented by leading and background indicators that influence and determine the coordination preparedness of adolescents aged 13-14 who are engaged in extreme MA.

Key words: coordination abilities, extreme motor activity, roller sports, skateboarding
Ірина Іванишин, Ігор Випасняк, Лідія Ковальчук, Юрій Іванишин. Кореляційна структура координаційної підготовленості підлітків 13-14-ти років чоловічої статі, які займаються екстремальними видами рухової активності

Анотація. Аналіз наукової літератури показав, що останніми роками екстремальний спорт розвивається дуже бурхливо, і вчені зацікавилися феноменом характеру особистості екстремального типу, зокрема, намагаючись з'ясувати, що керує людьми, які займаються екстремальними видами рухової активності. Мета дослідження - виявити наявність кореляційних зв'язків між показниками координаційних якостей та показниками основних психічних властивостей і процесів у підлітків 13-14-ти років, які займаються екстремальними видами рухової активності (РА). Матеріали і методи. У дослідженнях взяли участь підлітки чоловічої статі віком 13-14 років ( $\mathrm{n}=47)$, які займаються екстремальними видами РА. Для визначення кореляційних зв'язків між показниками психічного і фізичного компонентів використовували тетрахоричний коефіцієнт кореляції та коефіцієнт взаємної звяязаності Чупрова, для встановлення зв'язків між показниками координаційних якостей використано параметричний коефіцієнт кореляції БравеПірсона. Статистична обробка проводилася з використанням пакета прикладних програм Statistika 6.0. Результати. Дослідження структури координаційних здібностей досліджуваного контингенту дозволило виявити, що показники здатності до управління просторово-часовими характеристиками пов'язані 3 показниками локус-контролю $(0,44)$, стійкістю уваги $(-0,34)$, механічною $(-0,34)$ та логічною $(-0,32)$ памяяттю; здатність до диференціювання просторових параметрів рухів корелює з тривожністю $(0,64)$, локусконтролем $(-0,62)$, стійкістю уваги $(0,35)$ та механічною пам яттю $(-0,31)$; здатність до диференціювання часових параметрів руху корелює з показниками психічних властивостей (тривожності, стресостійкості та локус-контролю), а також показниками психічних процесів: механічною пам'яттю $(-0,47)$ та стійкістю уваги $(-0,38) ; з і$ здібністю до збереження статичної рівноваги корелює показник стресостійкості $(-0,32)$, а здатністю до збереження динамічної рівноваги - показники логічної пам'яті $(-0,51)$, стресостійкості $(0,35)$, локус-контролю $(0,37)$ і механічної пам'яті $(-0,37)$; зі здатністю до загальної координованості рухів корелювали показники соціальної бажаності $(0,49)$, механічної пам яті $(0,35)$ та локус-контролю $(-0,32)$. Висновки. Інтегральний показник координаційних здібностей представлений провідними та фоновими показниками, що впливають і обумовлюють координаційну підготовленість підлітків 13-14-ти років, які займаються екстремальними видами РА.

Ключові слова: координаційні здібності, екстремальні види рухової активності, роллеспорт, скейтбординг 


\section{Introduction}

In recent years, extreme sports have developed very rapidly $[15 ; 23 ; 26 ; 29]$, and scientists have interested in extreme personality phenomenon, in particular, trying to find out what drives people who engage in extreme motor activity (MA) types [25, 32; 33].

Frank Furley co-authored [30] studied most of the male representatives of this MA type. Scientists affirm that the "sensation seeking" is more common in adolescents aged 14-20 years, besides T-type people reject accepted norms and create their own world, moreover T-type must risk their lives to eliminate internal disharmony, whereas an ordinary person can be satisfied with a conversation.

I. N. Konopleva, Yu.S. Kalyagin [12], speaking about the subjects engaged in extreme activities, indicated that these people develop eustress or positive stress, that is positive stress effect on the body, namely stress level increasing, personal parameters and growth development, the realization of exertion need.

E. S. Epifanova [6] also considered extreme motor activity types as a means of stress resistance forming in adolescents.

T. N. Berezina [2] proved the close connection between thinking and balance as an integral coordination abilities indicator in adults. Other researchers [1; 10; 33] have suggested that in adolescents, engaged in extreme motor activity, flexibility of thinking depends on their coordination skills.

Age 13-14 years is considered to be a sensitive period for sensomotor reactions speed development, muscle differentiation accuracy, attention switching speed [4; 9; 14].

According to a number of researchers the formation of most psychomotor qualities related to mechanical reactions speed and accuracy ends at 15-16 years old $[7 ; 8 ; 18 ; 21]$, as well as perceptual sphere qualities $[13 ; 27 ; 28]$.

Data analysis of domestic and foreign scientists showed that the problem of correlation between coordination abilities and cognitive processes is poorly researched and fragmented, and thorough research on the studied parameters correlation for people engaged in extreme motor activity has not been identified [17].

The aim of the study was to identify the correlations between coordination qualities and basic mental properties and processes indicators in adolescents aged 13-14 years, who are engaged in extreme motor activity types.

\section{Materials and methods of research}

Study participants. The research was conducted on the basis of secondary schools of I-III grades № 5, 11, secondary schools of I-III grades № 17, 22, 23 of Ivano-Frankivsk.
Male adolescents aged 13-14 years participated in the study. Totally 47 adolescents, engaged in extreme physical activities, including skateboarding and rollerblading, were examined.

Study organization. To solve the tasks there were used the following research methods: scientific and methodological literature analysis, pedagogical testing of coordination abilities, psychodiagnostic method and mathematical statistics methods. To determine the coordination abilities there were proposed the following test tasks: spiral beep test (s), two change-of-direction maneuvers running (s), accuracy of 5-, 10- and 30 seconds time interval (s), walking straight with eyes closed $(\mathrm{cm})$, Yarotsky's test (c), BESS technique (points), test «gymnastic wall» (c), three forward rolls (c) [8]. Psychodiagnostic techniques: "Susceptibility to stress», "Study of total emotional orientation» by B. Dodonov, «Emotional and volitional qualities measuring technique» by Taylor Eysenck, Roong, Rotter processing by Kondratyeva, "Person's character quiz», «Personal Aggression and Conflict Questionnaire», «Logical and Mechanical Memory Test» and «Visual Reproduction Questionnaire» [11].

Statistical analysis. To determine the correlation between the indicators of psycho-emotional, psychomotor and physical (coordination) components, measured on a dichotomous scale, used a tetrachoric correlation coefficient $(\phi)$, and determining the correlation between features, having more than two gradations, there was used Chuprov's coefficient of mutual conjugacy (C); the parametric Brave-Pearson correlation coefficient $(r)$ was used for the features measured in ratio scale. Statistical processing of the material was performed on a personal computer using the package "Statistics 6.0».

\section{Results of the research}

As a result of correlation analysis of the structuralfunctional model of the coordination component of adolescents aged 13-14, engaged in roller sports and skateboarding, there was found 40 close relationships $(20.0 \%)(0.30<C<1.00)$ of 200 calculated correlations between 9 coordination abilities indicators in the extreme profile.

Strong correlations between coordination abilities indicators, on the one hand, and mental properties and processes indicators, on the other hand, were understood as those in which increasing of studied abilities development level can lead to improving of interrelated mental processes indicators in the studied contingent. Such correlations were determined both between the indicator of integrated coordination abilities (IICA) and between their individual indicators and mental properties and processes indicators (Table 1). 
Table 1 - Correlation between coordination abilities and mental processes indicators of adolescents engaged in extreme motor activity types

\begin{tabular}{|l|c|c|c|c|c|c|c|c|c|c|}
\hline \multirow{2}{*}{ Psychological indicators } & \multicolumn{9}{|c|}{ Tests } & \multicolumn{1}{|c|}{ IICA } \\
\cline { 2 - 11 } & 1 & 2 & 3 & 4 & 5 & 6 & 7 & 8 & 9 & 0.07 \\
\hline Proneness to stress & 0.08 & $\mathbf{0 . 3 7}$ & $\mathbf{0 . 4 6}$ & 0.26 & 0.09 & $\mathbf{0 . 3 2}$ & $\mathbf{0 . 3 5}$ & 0.21 & 0.15 & 0.28 \\
\hline Anxiety & 0.03 & 0.06 & 0.28 & $\mathbf{0 . 3 4}$ & $\mathbf{0 . 6 4}$ & 0.24 & 0.09 & 0.19 & 0.20 & 0.24 \\
\hline Impulsivity & 0.06 & 0.26 & 0.15 & 0.22 & 0.16 & 0.04 & - & 0.24 & $\mathbf{0 . 3 0}$ & 0.23 \\
\hline Dogma & 0.19 & 0.27 & 0.08 & 0.02 & 0.24 & $\mathbf{0 . 3 2}$ & $\mathbf{0 . 3 5}$ & 0.15 & $\mathbf{0 . 4 6}$ & 0.10 \\
\hline Locus of control & $\mathbf{0 . 4 4}$ & 0.27 & $\mathbf{0 . 6 0}$ & 0.01 & $\mathbf{0 . 6 2}$ & 0.26 & $\mathbf{0 . 3 7}$ & 0.25 & $\mathbf{0 . 3 2}$ & $\mathbf{0 . 7 7}$ \\
\hline Ocial-desirability bias & 0.18 & 0.08 & $\mathbf{0 . 4 1}$ & 0.28 & 0.08 & 0.09 & 0.17 & $\mathbf{0 . 4 9}$ & $\mathbf{0 . 3 7}$ & $\mathbf{0 . 4 8}$ \\
\hline Ardency & 0.03 & 0.10 & 0.09 & 0.20 & $\mathbf{0 . 3 8}$ & 0.21 & 0.10 & 0.15 & 0.11 & 0.05 \\
\hline Assertiveness & 0.07 & 0.14 & 0.26 & 0.07 & 0.17 & 0.12 & 0.09 & 0.09 & 0.01 & 0.17 \\
\hline Vulnerability & 0.04 & 0.08 & 0.09 & 0.26 & $\mathbf{0 . 3 7}$ & 0.23 & 0.06 & 0.13 & 0.11 & 0.05 \\
\hline Disobedience & 0.16 & 0.21 & 0.02 & 0.09 & 0.03 & 0.22 & 0.13 & 0.19 & 0.22 & 0.13 \\
\hline Uncompromise & 0.05 & 0.06 & 0.12 & 0.01 & 0.18 & 0.12 & $\mathbf{0 . 3 0}$ & 0.10 & 0.17 & 0.02 \\
\hline Vindictiveness & 0.01 & 0.06 & 0.13 & 0.08 & 0.02 & 0.20 & 0.15 & 0.01 & 0.11 & 0.08 \\
\hline Impatience & 0.06 & 0.02 & - & 0.05 & 0.05 & 0.14 & 0.20 & 0.08 & 0.07 & 0.07 \\
\hline Suspiciousness & 0.01 & 0.14 & 0.04 & 0.06 & 0.06 & 0.24 & 0.28 & 0.01 & 0.20 & 0.01 \\
\hline Positive aggression & 0.18 & 0.10 & 0.35 & 0.08 & 0.21 & 0.10 & $\mathbf{0 . 3 1}$ & 0.11 & 0.06 & 0.27 \\
\hline Negative aggression & 0.01 & 0.18 & 0.13 & 0.02 & 0.15 & 0.14 & 0.04 & 0.10 & 0.14 & 0.16 \\
\hline Conflictness & - & 0.03 & 0.08 & 0.25 & $\mathbf{0 . 4 3}$ & 0.17 & 0.14 & 0.12 & 0.21 & 0.04 \\
\hline Alertness & $\mathbf{0 . 3 4}$ & $\mathbf{0 . 3 5}$ & $\mathbf{0 . 3 8}$ & 0.17 & 0.08 & 0.01 & 0.21 & 0.30 & 0.36 & 0.27 \\
\hline Logical memory & $\mathbf{0 . 3 2}$ & 0.12 & 0.04 & 0.10 & 0.26 & 0.20 & $\mathbf{0 . 5 1}$ & 0.18 & 0.28 & $\mathbf{0 . 4 4}$ \\
\hline Mechanical memory & $\mathbf{0 . 3 4}$ & $\mathbf{0 . 0 7}$ & 0.17 & 0.18 & $\mathbf{0 . 3 1}$ & 0.16 & $\mathbf{0 . 3 7}$ & $\mathbf{0 . 3 5}$ & $\mathbf{0 . 3 3}$ & $\mathbf{0 . 4 8}$ \\
\hline
\end{tabular}

Not e s 1) 1 -spiral beep test; 2 - two change-of-direction maneuvers running; 3 - accuracy of 5 seconds time interval; 4 - accuracy of 30 seconds time interval; 5 - walking straight with eyes closed; 6-Yarotsky's test; 7 - BESS technique; 8 - three forward rolls; 9 - test «gymnastic wall»;

2) strong correlations are marked bold

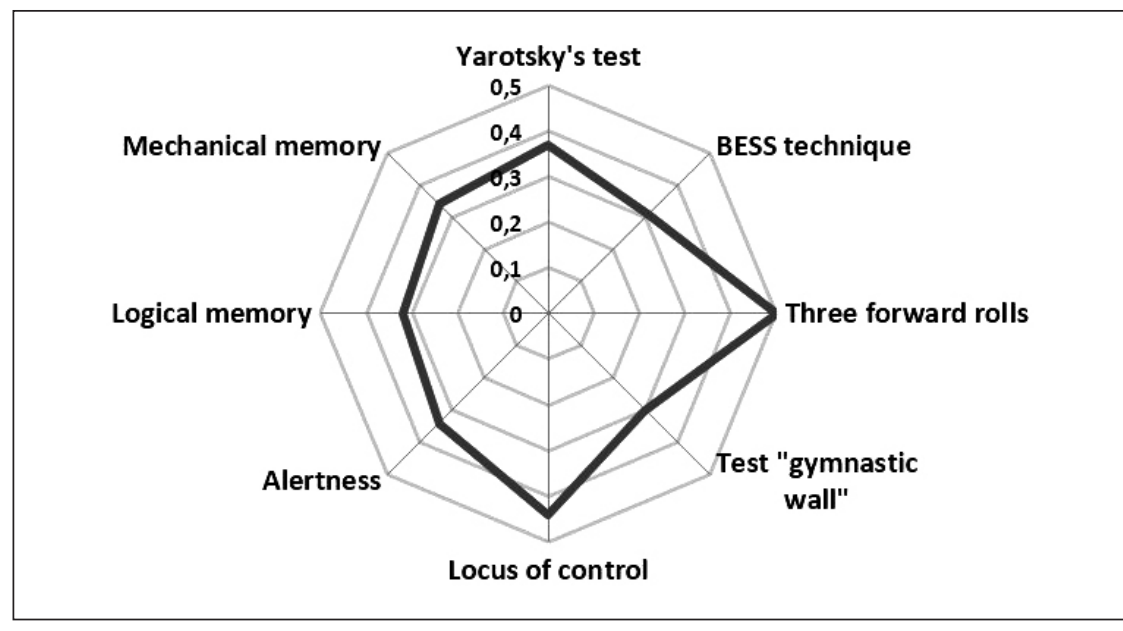

Fig. 1 Correlations between the integrated ability indicator to spatio-temporal characteristics managing and coordination abilities, basic mental properties and processes indicators in the studied contingent

Fig. 1 presents a correlogram that shows the correlations between the integrated ability indicator to spatio-temporal characteristics managing and basic mental properties and processes indicators, as well as other coordination abilities types indicators of adolescents 13-14 years engaged in extreme MA types.

As can be seen from Fig. 1, improving the ability indicator to spatio-temporal characteristics managing can lead to indicators improving of static $(C=0.37 ; p<0.05)$, dynamic $(C=0.31 ; p<0.05)$ balance, overall movements coordination (according to tests results of three forward rolls $(C=0.50 ; p<0.05)$ and gymnastic wall climbing $(C=0.30 ; p<0.05))$, the locus of control indicator $(C=0.44 ; p<0.05)$, as well as indicators of alertness $(C=0.34 ; p<0.01)$, logical $(C=0.32 ; p<0.05)$ and mechanical $(C=0.34 ; p<0,05)$ memory. 


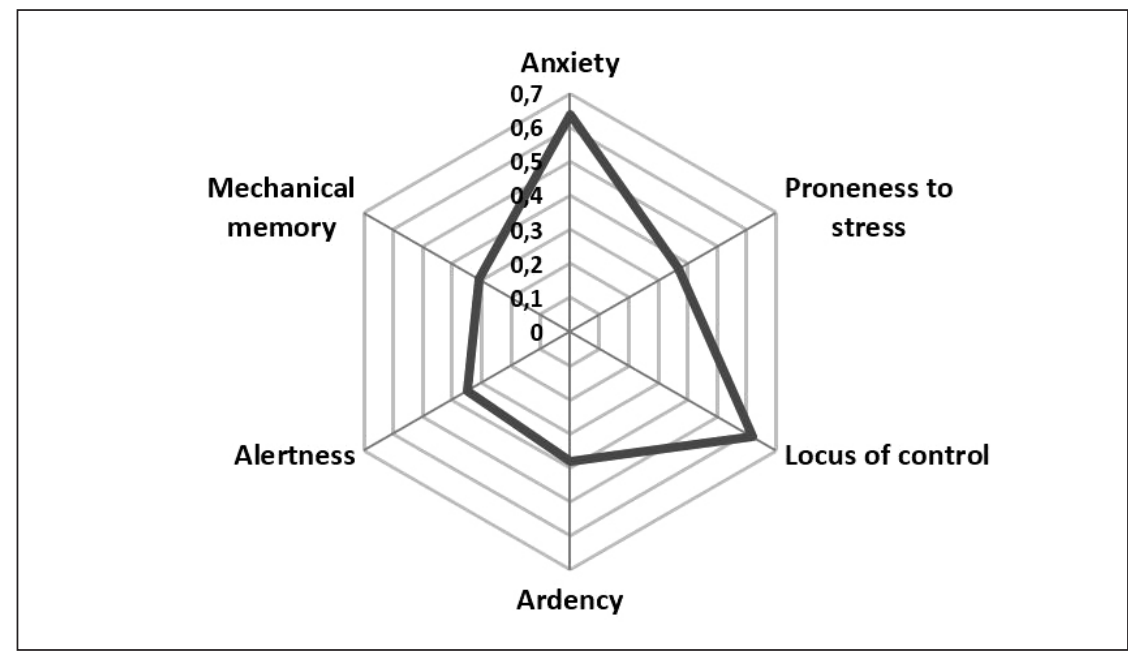

Fig. 2 Correlation between the ability to manage spatial characteristics and basic mental properties and processes indicators in adolescents aged 13-14 years, engaged in extreme MA

In Fig. 2 a correlation scheme of relationships between the ability indicator to differentiate the spatial movements parameters and main mental properties and processes indicators of the studied contingent is shown.

Therefore, the ability indicator to manage the spatial movements parameters correlates with the indicators of alertness $(C=0.35 ; p<0.05)$, mechanical memory ( $\mathrm{C}=0.31 ; \mathrm{p}<0.05)$, as well as locus control ( $C=0.62 ; p<0.05)$. It should be noted that exercises that develop this coordination ability type are associated with a high anxiety level $(C=0.64 ; p<0.05)$ and ardency $(C=0.38 ; p<0.05)$, which, in our opinion, is due to new activities not included in school curriculum.

Examining the correlations between indicators of spatial movements parameters differentiation and other studied indicators, we can confirm that exercises, aiming at this coordination abilities type development, have a positive effect on ability to spatial characteristics differentiation ( $C=0.39 ; p<0.05)$, to dynamic balance
( $C=0.39 ; p<0.05)$, mental properties indicators (anxiety, stress and locus control), as well as mental processes indicators: alertness $(C=0.38 ; p<0.05)$ and mechanical memory ( $C=0.47 ; p<0.05$ ) (Fig. 3 ).

Correlation analysis showed that in male adolescents engaged in extreme MA the ability to dynamic balance $(C=0.37 ; p<0.05)$ and proneness to stress $(C=0.32 p<0.05)$ correlates with ability to maintain static balance.

As for dynamic balance ability, it has a greater number of authentic correlations (Fig. 4). It turned out that adolescents who engage in extreme MA, there is a correlation between the ability to dynamic balance with logical memory ( $C=0.51 ; p<0.05)$, the integrated ability to coordinate movements ( $C=0.49 ; p<0,05)$, as well as with such psyche properties as proneness to stress ( $C=0.35 ; p<0,05)$, locus control $(C=0,37 ; p<0,05)$, mechanical $(C=0.37 ; p<0.05)$ and logical $(C=0.51$; $\mathrm{p}<0.05)$ memory indicators.

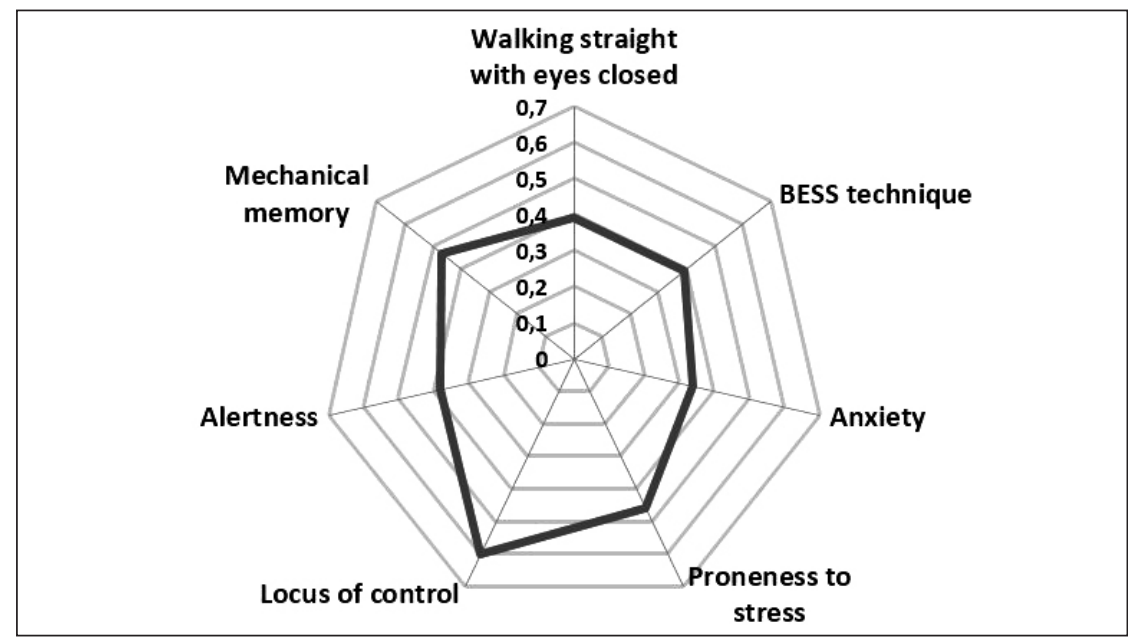

Fig. 3 Correlations between the ability temporal characteristics managing and coordination abilities, basic mental properties and processes indicators in adolescents aged 13-14 years engaged in extreme MA 


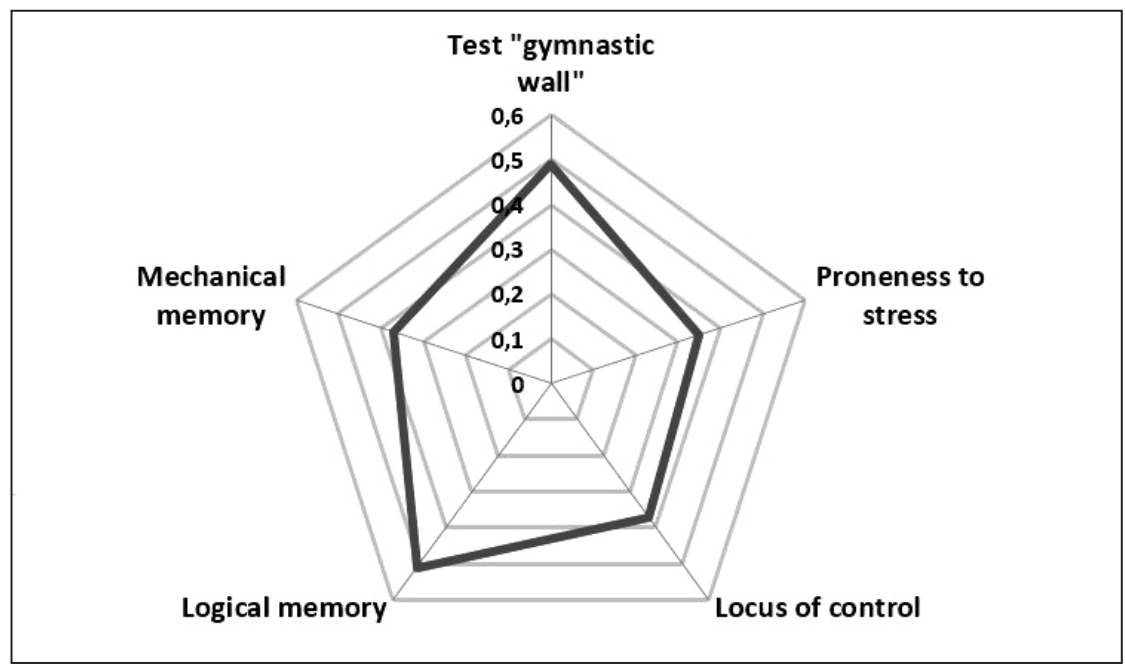

Fig. 4 Correlation between the ability indicators to dynamic balance and coordination abilities, basic mental properties and processes indicators in adolescents aged 13-14 years engaged in extreme MA

In adolescents aged 13-14 years engaged in extreme MA, locus control $(C=0.32 ; p<0.05)$, social desirability $(C=0.49 ; p<0.05)$ and mechanical memory correlated with the ability indicator to general movements coordination ( $C=0.35 ; p<0.05$ ).
Besides, in "Gymnastic wall» test can be additionally noted correlation with alertness $(C=0.40 ; p<0.05)$.

The relationship between 7 indicators of different coordination abilities types was also analyzed. Totally 36 correlations were considered (Fig. 5).

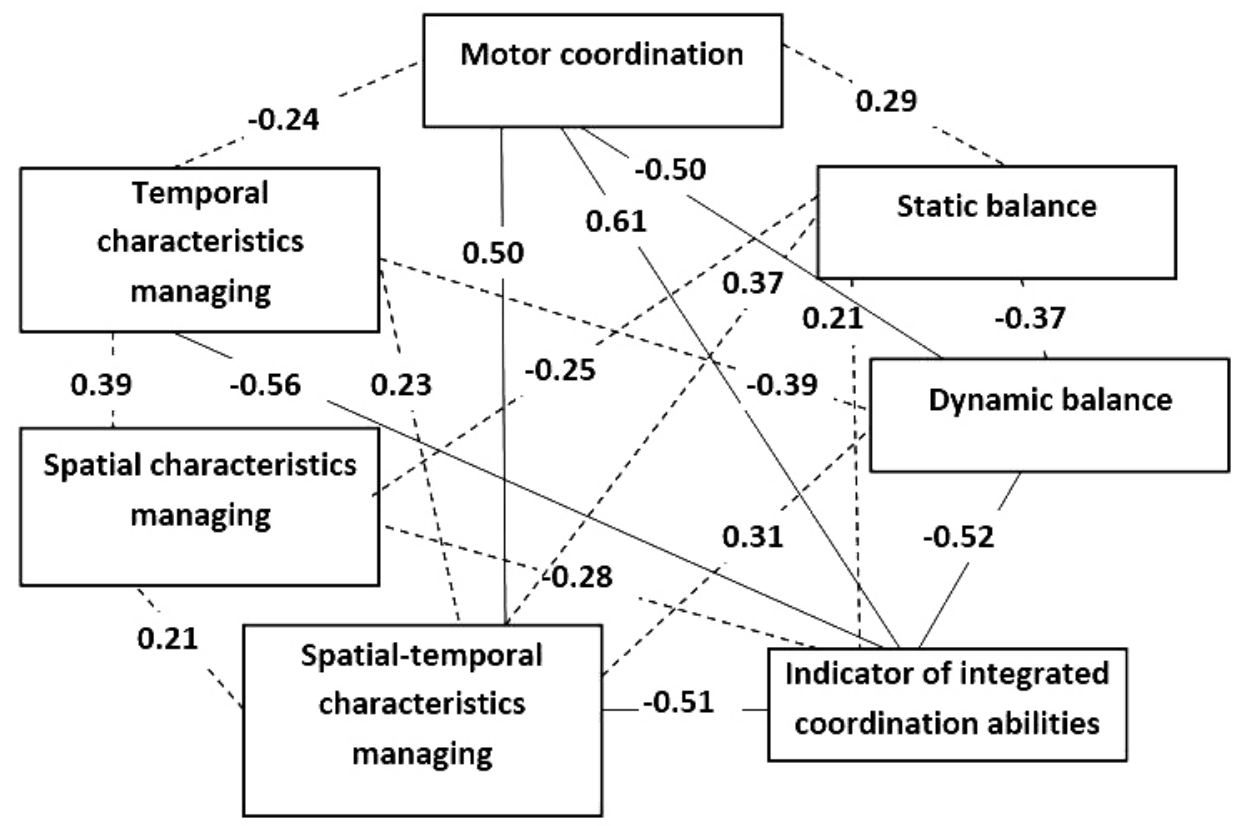

Fig. 5 Correlations between the coordination abilities of 13-14 years old adolescents engaged in extreme motor activity: moderate correlation, - weak correlation

Analysis of correlation matrix results showed a significant moderate correlation $(|r| \geq 0.50)$ between the integrated coordination abilities indicator and the motor coordination ability $(r=0.61 ; p<0.05)$, the temporal $(r=0,56 ; p<0.05)$, spatio-temporal $(r=-0.51 ; p<0.05)$ characteristics managing and dynamic balance ability $(r=-0.52 ; p<0.05)$. Weak relationships $(|r| \geq 0.20)$ were observed between IICA and the ability to spatial characteristics managing $(r=-0.28 ; p<0.05)$.

Moderate correlation was also observed between motor coordination ability and ability to differentiate spatio-temporal characteristics managing $(r=0.50 ; p<0.05)$ and dynamic balance $(r=-0.50 ; p<0,05)$.

Significant weak relationships were observed between all other coordination abilities types. 


\section{Discussion}

The analysis of studied sources shows that scientists on physical culture and sports are constantly working to find ways to improve the physical education process efficiency of students. Much attention has been paid to modern innovative technologies development and implementation in sports and recreation work of secondary schools, aimed at updating the physical education forms and content [24 ].

Thus, I. Yu. Gorska, I. V. Averyanov, A. M. Kondakov [5] pointed out the importance of BMX-race sports impact on young athletes coordination abilities. M. S. Prudnikova [20] investigated the positive extreme cycling impact on 12-13 years old girls' physical development.

According to research, in educational institutions that implement non-Olympic and innovative sports, the effectiveness of extracurricular physical education forms is significantly increasing, that is increasing of the number of adolescents, attending clubs and sections by $64.0 \%$. $30.5 \%$ of adolescents indicate that their schools have innovative sports clubs and sections, such as minigolf (SNAG), darts, bowling, etc. [3; 19]. The analysis of psycho-emotional state of 13-14-year-old adolescents confirmed the experts data that most of them $(61.9 \%$ of respondents) have a high anxiety level $[6 ; 12]$, low locuscontrol $[18 ; 25 ; 28]$.

Research has also confirmed that adolescents engaged in extreme physical activity have higher intellectual development rates, namely different memory properties [10; 30]. There were developed the results of M. G. Samoilova [22] research that the highest effectiveness of physical culture means using for emotional and volitional qualities formation in adolescents is observed in overcoming challenges, characteristic for extreme activities. There were also developed I. Nakonechny [16] data on the positive impact of extreme motor activity on behavior self-regulation development level of adolescents in training process.

Thus, we have shown that the motor coordination problems are closely connected with problems of attention, low self-esteem and self-respect and other emotional problems, making parents, teachers and other professionals

Джерела та література

1. Абабков В. А., Пере М. Адаптация к стрессу. Основы теории, диагностики, терапии. СПб.: Речь, 2004. 166 с.

2. Березина Т.Н. О взаимодействии физических и интеллектуальных способностей. NB: Психология и психотехніка. 2012. №1. С. 1-24. Режим доступа: https://nbpublish.com/library_read_article. php?id=47.

3. Бондарь Т. С., Ротерс Т. Т. Актуальные проблемы физического воспитания подростков в детских учреждениях оздоровления и отдыха. Физическое воспитание студентов. 2012. №3. C. 15-18. Режим доступа: https://sportedu.org.ua/html/ journal/2012-N3/12btsmhr.pdf. think about this. Studies have found that adolescents with coordination problems perceive themselves as having low physical competence as a result of their repeated failures in motor skills. At least, persistent failure leads to despair and anxiety [4].Having studied the correlation indicators between different coordination abilities and the main mental properties and processes characteristics, it was found that in 13-14 years old male adolescents engaged in extreme MA, while developing individual coordination skills in training process, there can be promoted their perceptual and cognitive spheres development [31]. The obtained results can be used for trainings and special classes development aimed at thinking development through the coordination skills training.

Thus, the correlation analysis results can be considered as a basis for coordination training programs development for adolescents and not only, involving the extreme MA using to increase the formation level both these qualities and personality perceptual and cognitive indicators.

\section{Conclusions}

Examining the correlation indicators between different coordination abilities and the main mental sphere characteristics of 13-14 years old male adolescents engaged in extreme MA, it was found that developing individual coordination skills in the training process, you can purposefully promote their thinking development and change locus control.

Analysis of coordination abilities correlation structure showed that the integrated coordination abilities indicator is represented by leading (ability to coordinate movements, differentiation of temporal, spatio-temporal movement parameters, ability to dynamic balance) and background (ability to differentiate spatial parameters) indicators influencing and determining the coordination abilities of adolescents aged $13-14$ by extreme MA means.The study will select the most effective means of adolescents' coordination qualities developing who intend to be engaged in extracurricular activities of extreme physical activity.

Conflict of interests. The authors declare no interest conflict.

1. Ababkov, V. A., Pere, M. (2004). Adaptatsiya k stressu. Osnovnye teorii, diagnostika, terapii [Adaptation to a stress. Main theories, diagnostics, therapies] Sankt Petersburg: Rech`. [in Russian].

2. Berezina, T. N. (2012). O vzaimodejstvii fizicheskikh i intellektual `ny `kh sposobnostej [The relation between indicators of physical and cognitive abilities]. NB: Psikhologiya i psikhotekhni ka, (1), 1-24. Retrieved from: https://10.7256/2306-0425.2012.1.47. https://nbpublish.com/library_read_article.php?id=47. [in Russian].

3. Bondar', T. S., Roters, T. T. (2012). Aktual'ny`e problemy` fizicheskogo vospitaniya podrostkov $v$ detskikh uchrezhdeniyakh ozdorovleniya i otdy 'kha [The issue of the day of physical education of teenagers in children' establishments of making healthy and rest]. Fizicheskoe vospitanie studentov, (3), 15-18. Retrieved from: https://sportedu. org.ua/html/journal/2012-N3/12btsmhr.pdf. [in Russian]. 
4. Гершкович В. А., Морошкина Н. В., Аллахвердов В. М., Иванчей И. И., Морозов М. И., Карпинская В. Ю., Кувалдина М. Б., Волков Д. Н. Возникновение повторяющихся ошибок в процессе сенсомоторного научения и способы их коррекции. Вестник С-Петерб. Университета. 2013. Вып. 16(3). С. 43-54. Режим доступа: https://cyberleninka.ru/article/n/vozniknoveniepovtoryayuschihsya-oshibok-v-protsesse-sensomotornogonaucheniya-i-sposoby-ih-korrektsii/viewer.

5. Горская И. Ю., Аверьянов И. В., Кондаков А. М. Координационная подготовка спортсменов : монография. Омск : Изд-во СибгУФК, 2015. 220 с. Режим доступа: http://biblioclub.ru/index.php?page=book\&id=429341.

6. Епифанова Е. С. Экстремальные виды активности как форма формирования стрессоустойчивости тинейджеров. Психолог. 2014 № 5. C. 16-38. DOI: https://doi.org/10.7256/2306-0425.2014. 5.13238.

7. Ильин Е. П. Психомоторная организация человека. СПб.: Питер, 2003. 384 c.

8. Іванишин Ю., Ковальчук Л., Іванишин І. Порівняльна характеристика координаційних здібностей підлітків, які займаються різними видами рухової активності. Вісник Прикарпатського університету. Серія: Фізична культура. 2017. №27-28.С. 104-110.

9. Іванюра І. О. Особливості розвитку деяких функцій вищої нервової діяльності в учнів середнього шкільного віку при тривалих фізичних навантаженнях. Фізіологічний журнал. 2000. №46(1). С. 94-100.

10. Козьяков Р. В., Орлова Е. А., Петрова Е. А., Еремин М. В. Особенности взаимосвязи эмоционального интеллекта и копинг-стратегий подростков, занимающихся экстремальными видами спорта. Теория и практика физической культуры. 2017. №4. С. 26-28.

11. Комінко С. Б., Кучер Г. В. Кращі методи психодіагностики. Тернопіль: Карт-бланш, 2005. 406 с.

12. Коноплева И. Н., Калягин Ю. С. Саморегуляция психических состояний как элемент психологической готовности к деятельности в экстремальных условиях. Психология и право. 2011. №1(4). Режим доступа: https://psyjournals.ru/psyandlaw/2011/ n4/49298.shtml.

13. Лизогуб В. С., Харченко Д. М., Хоменко С. М., Юхименко Л. І., Петренко Ю.О., Явник О.Е. Онтогенез нейродинамічних функцій людини. Фізіологічний журнал. 2002. №48(2). С. 123-124.

14. Любомирский Л.Е. Закономерности развития сенсомоторных функций у детей школьного возраста: автореф. дис. ... доктора биол. наук: 03.00.13. Научно-исследовательский институт физиологии детей и подростков. Москва, 1989. 32 с. Режим доступа: http://earthpapers.net/preview/417915/a?\#?page=32.

15. Моргунова Г. Е. Социокультурная среда города как фактор формирования современной молодежной субкультуры: автореф. дис. ... канд. культурологи: 24.00.01. Кемеровский государственный университет. 2010. 25 с. Режим доступа: https://www.dissercat.com/ content/sotsiokulturnaya-sreda-goroda-kak-faktor-formirovaniyasovremennoi-molodezhnoi-subkultury.

16. Наконечний І. Ю. Аналіз та оцінка ефективності застосування програми розвитку саморегуляції поведінки підлітків на заняттях з панкратіону. Науковий часопис Національного педагогічного університету імені М. П. Драгоманова. Серія 12: Психологічні науки. 2012. №38. С. 105-112. Режим доступу: http://nbuv.gov.ua/ UJRN/Nchnpu_012_2012_38_17.

17. Носко М., Єдинак Г. Передумови персоналізації в розвитку координації учнів початкової школи. Вісник Кам'янець-Подільського національного університету. Фізичне виховання, спорт і здоров'я людини. 2019. Вип. 14. С. 36-40. doi: 10.32626/22276246.2019-14.36-40.

18. Озеров В. П. Психомоторные способности человека. Дубна: Феникс-Плюс. 2002. 320 с.

19. Пигарева К.О. Формирование неосознаваемой мотивации занятий экстремальными видами спорта: психодинамический подход. Проблеми екстремальної та кризової психології. 2013. №14(II). С. 261-270. Режим доступа: http://nbuv.gov.ua/UJRN/ Pekp_2013_14(2)_37.
4. Gershkovich, V. A., Moroshkina, N. V., Allakhverdov, V. M., Ivanchej, I. I., Morozov, M. I., Karpinskaya, V. Yu., Kuvaldina, M. B., Volkov, D. N. (2013). Vozniknovenie povtoryayushhikhsya oshibok v proczesse sensomotornogo naucheniya i sposoby` ikh korrekczii [The occurrence of repetitive errors in the process of sensomotor training and ways of their correction]. Vestnik S-Peterb. Universiteta, 16(3), 43-54. Retrieved from: https://cyberleninka.ru/article/n/vozniknoveniepovtoryayuschihsya-oshibok-v-protsesse-sensomotornogo-naucheniya-isposoby-ih-korrektsii/viewer.[in Russian].

5. Gorskaya I. Yu., Aver yanov I. V., Kondakov A. M. Koordinaczionnaya podgotovka sportsmenov [Coordination training for athletes]. Ministerstvo sporta Rossijskoj Federaczii, Sibirskij gosudarstvenny`j universitet fizicheskoj kul 'tury` i sporta. Omsk: Izd-vo SibGUFK, 2015. Retrieved from: http://biblioclub.ru/index.php?page=book\&id=429341. [in Russian].

6. Epifanova, E. S. (2014). E’kstremal'ny`e vidy` aktivnosti kak forma formirovaniya stressoustojchivosti tinejdzherov [Extreme activity as a form of the formation of stress resistance in teenagers]. Psikholog, (5), 16-38. DOI: https://doi.org/10.7256/2306-0425.2014.5.13238. [in Russian].

7. II'in, E. P. (2003). Psikhomotornaya organizacziya cheloveka [Psychomotor organization of a person]. SPb.: Piter. 384 p. [in Russian].

8. Ivanyshyn, Yu., Kovalchuk, L., Ivanyshyn, I. (2017). Porivnialna kharakterystyka koordynatsiinykh zdibnostei pidlitkiv, yaki zaimaiutsia riznymy vydamy rukhovoi aktyvnosti [Comparative characteristics of coordination abilities of adolescents engaged in different types of motor activity]. Visnyk Prykarpatskoho universytetu. Seriia: Fizychna kultura, (27-28), 104-110. [in Ukrainian].

9. Ivaniura, I. O. (2000). Osoblyvosti rozvytku deiakykh funktsii vyshchoi nervovoi diialnosti v uchniv serednoho shkilnoho viku pry tryvalykh fizychnykh navantazhenniakh [Features of the development of some functions of higher nervous activity in middle school students during prolonged physical activity]. Fiziolohichnyi zhurnal, 46(1), 94-100. [in Ukrainian].

10. Koz yakov, R. V., Orlova, E. A., Petrova, E. A., Eremin, M. V. (2017). Osobennosti vzaimosvyazi e`moczional'nogo intellekta i koping-strategij podrostkov, zanimayushhikhsya e'kstremal'ny'mi vidami sporta [Effects of extreme adolescent sports on emotional intelligence and coping strategies]. Teoriya i praktika fizicheskoj kul 'tury', (4), 26-28. [in Russian].

11. Kominko, S.B., Kucher, H.V. (2005). Krashchi metody psykhodiahnostyky [The best methods of psychodiagnostics]. Ternopil: Kart-blansh. 406 p. [in Ukrainian]

12. Konopleva, I. N., Kalyagin, Yu. S. (2011). Samoregulyacziya psikhicheskikh sostoyanij kak e`lement psikhologicheskoj gotovnosti k deyatel'nosti v e`kstremal 'ny 'kh usloviyakh [Self-regulation of psychic conditions as an element of psychological readiness to act in extreme conditions]. Psikhologiya i pravo, 1(4). Retrieved from: https:// psyjournals.Su/psyandlaw/2011/n4/49298.shtml. [in Russian].

13. Lyzohub, V. S., Kharchenko, D. M., Khomenko, S. M., Yukhymenko, L. I., Petrenko, Yu. O., Yavnyk, O. E. (2002). Ontohenez neirodynamichnykh funktsii liudyny [Ontogenesis of neurodynamic functions of a person]. Fiziolohichnyi zhurnal, 48 (2), 123-124. [in Ukrainian].

14. Lyubomirskij, L. E. (1989). Zakonomernosti razvitiya sensomotorny`kh funkczij u detej shkol'nogo vozrasta [Regularities of the development of sensorimotor functions in school-age children]. Extended abstract of doctor's thesis. Nauchno-issledovatel'skij institut fiziologii detej i podrostkov. Moskow. Retrieved from: http://earthpapers.net/ preview/417915/a?\#?page=32. [in Russian].

15. Morgunova, G. E. (2010). Socziokul turnaya sreda goroda kak faktor formirovaniya sovremennoj molodezhnoj subkul'tury' [Sociokulture city environment as a factor of the formation modern culture of the young peoples]. Extended abstract of candidate's thesis. Kemerovskij gosudarstvenny juni versitet]. Kemerovo. Retrieved from: https://www. dissercat.com/content/sotsiokulturnaya-sreda-goroda-kak-faktorformirovaniya-sovremennoi-molodezhnoi-subkultury. [in Russian].

16. Nakonechnyi I.Iu. (2012). Analiz ta otsinka efektyvnosti zastosuvannia prohramy rozvytku samorehuliatsii povedinky pidlitkiv na zaniattiakh $z$ pankrationu [Analysis and evaluation of the effectiveness of the program for the development of self-regulation of adolescent behavior in pankration classes]. Naukovyi chasopys Natsionalnoho pedahohichnoho universytetu imeni M. P. Drahomanova. Seriia 12: Psykholohichni nauky, (38), 105-112. Retrieved from: http://nbuv. gov.ua/UJRN/Nchnpu_012_2012_38_17. [in Ukrainian]. 
20. Пруднікова М. С. Вплив тренувального процесу на морфофункціональні показники юних велосипедистів 13-14 років (на матеріалі велосипедного мотокросу). Слобожанський науковоспортивний вісник. 2012. №4(31). С. 91-96. Режим доступа: http:// journals.uran.ua/index.php/1991-0177/article/view/21940.

21. Ровный А. С., Галимский В. А., Ровная О. А. Роль сенсорных систем в управлении сложно-координированными движениями спортсменов. Слобожанський науково-спортивний вісник. 2014 №3. C. 78-85. DOI: https://doi.org/10.15391/snsv.2014-3.016.

22. Самойлов М. Г. Об'єктивні та суб'єктивні чинники, від яких залежить екстремальність виду спорту і спортивні результати. Слобожанський науково-спортивний вісник. 2008. Вип. 1-2. С. 178-182.

23. Темнов А. Экстремальные виды спорта. Зависимость или хобби для активных людей? Основы безопасности жизнедеятельности. 2013. №5. С. 36-40.

23. Temnov, A. (2013). E`kstremal `ny`e vidy`sporta. Zavisimost` ili khobbi dlya aktivny 'kh lyudej? [Extreme types of sports - dependence or hobby for active people]. Osnovy bezopasnosti zhiznedeyatel'nosti, (5), 36-40. [in Russian].

24. Breivik, G. (2010). Trends in adventure sports in a post-modern society. Sport in Society, (13), 260-273. DOI: https://doi. org/10.1080/17430430903522970.

25. Brymer, E., Schwitzer, R. (2012). Extreme sports are good for your health: a phenomenological understanding of feaur and anxiety in extreme sport. J Health Psychol., 18 (4), 447-487. DOI: $10.1177 / 1359105312446770$.

26. Devon, O'Neil. X Games expands globally. Retrieved from: http:// www.xgames.com/action/cities/article/7862758/x-games-growthree-six-events-2013.

27. ledynak, G., Galamandjuk, L., Dutchak, M., Balatska, L., Herasymchuk, A. \& Mazur, V. (2017). Effectiveness of Different Options when Teaching Children Basic Movements due to Certain Handedness. Journal of Physical Education and Sport, 17(2), 582-589. DOI:10.7752/ jpes.2017.02088.

28. Inchley, J., Kirby, J., Currie, C. (2011). Longitudinal changes in physical selfperceptions and associations with physical activity during adolescence. Pediatric Exercise Science, 23(2), 237-249. DOI: https:// doi.org/10.1123/pes.23.2.237.

29. Mei-Dan, O., Carmont, M. R. (2013). Introduction. Adventure and extreme sports: Epidemiology, Treatment, Rehabilitation and Prevention. New-York Springer-Verlag, 1-5. DOI: https://doi. org/10.1007/978-1-4471-4363-5.

30. Reyna, V., Farley, F. (2006). Risk and rationality in adolescent decision making: Implications for theory, practice, and public policy. Psychological Science in the Public Interest, Sep.7(1), 1-44. DOI: https://doi.org/10.1111/j.1529-1006.2006.00026.x.

31. Van der Fels, Irene M.J., te Wierike, Sanne C.M., Hartman, E., Elferink, Marije T., Smith, J., Visscher, $\mathrm{Cr}$. The relationship between motor skills and cognitive skills in 4-16 year old typically developing children: A systematic review. Journal of Science and Medicine in Sport, 18(6), 697-703. DOI: https://doi.org/10.1016/j.jsams.2014.09.007.

32. Willig, C.A. (2008). Phenomenological investigation of the experience of taking part in 'extreme sports'. J Health Psychol., 13(5), 690-702. DOI: https://doi.org/10.1177/1359105307082459.

33. Woodman, T., Hardy, L., Barlow, M., Le Scanff, C. (2010). Motives for participation in prolonged engagement high-risk sports: An agentic emotion regulation perspective. Psychology of Sport and Exercise, (11), 345-352. DOI: https://doi.org/10.1016/j.psychsport.2010.04.002.
17. Nosko M., ledynak G. (2019). Peredumovy personalizatsii v rozvytku koordynatsii uchniv pochatkovoi shkoly [Prerequisites of personalization in the development of coordination primary school pupils]. Bulletin of Kamyanets-Podilskyi Ivan Ogiyenko National University. Physical Education, Sports and Human Health, (8), 156-162. [in Ukrainian].

18. Ozerov, V. P. (2002). Psikhomotorny’e sposobnosti cheloveka [Human psychomotor abilities]. Dubna: Feniks-Plyus. 320 p. [in Russian].

19. Pigareva, K. O. (2013). Formirovanie neosoznavaemoj motivaczii zanyatij e'kstremal'ny'mi vidami sporta: psikhodinamicheskij podkhod [Forming of the unrealized motivation of employments extreme types of sport: psikhodinamicheskiy approach]. Problemy ekstremalnoi ta kryzovoi psykholohii, 14(II), 261-270. Retrieved from: http://nbuv.gov.ua/UJRN/Pekp_2013_14(2)_37. [in Russian].

20. Prudnikova, M. S. (2012). Vplyv trenuvalnoho protsesu na morfofunktsionalni pokaznyky yunykh velosypedystiv 13-14 rokiv (na materiali velosypednoho motokrosu) [Research of influence of training process on the morph functional indexes of young bicyclists 13-14 years (on material BMÕ-Racing]. Slobozhanskyi naukovosportyvnyi visnyk, 4(31), 91-96. Retrieved from: http://journals.uran. ua/index.php/1991-0177/article/view/21940. [in Ukrainian].

21. Rovny`j, A. S., Galimskij, V. A., Rovnaya, O. A. (2014). Rol` sensorny`kh sistem $v$ upravlenii slozhno-koordinirovanny'mi dvizheniyami sportsmenov [The role of sensory systems in the management of difficult-coordinated movements of athletes]. Slobozhanskyi naukovo-sportyvnyi visnyk, (3), 78-85. https://doi.org/10.15391/ snsv.2014-3.016. [in Russian].

22. Samoilov, M. H. (2008). Obiektyvni ta subiektyvni chynnyky, vid yakykh zalezhyt ekstremalnist vydu sportu i sportyvni rezultaty [Objective and subjective factors effect on sports extremity and sports results]. Slobozhanskyi naukovo-sportyvnyi visnyk, (1-2), 178-182. [in Ukrainian].

23. Temnov, A. (2013). E`kstremal `ny`e vidy`sporta. Zavisimost` ili khobbi dlya aktivny'kh lyudej? [Extreme types of sports - dependence or hobby for active people]. Osnovy bezopasnosti zhiznedeyatel 'nosti, (5), 36-40. [in Russian].

24. Breivik, G. (2010). Trends in adventure sports in a post-modern society. Sport in Society, (13), 260-273. DOI: https://doi.org/10.1080/ 17430430903522970.

25. Brymer, E., Schwitzer, R. (2012). Extreme sports are good for your health: a phenomenological understanding of feaur and anxiety in extreme sport. $J$ Health Psychol., 18 (4), 447-487. DOI: 10.1177/1359105312446770.

26. Devon, O’Neil. X Games expands globally. Retrieved from: http:// www.xgames.com/action/cities/article/7862758/x-games-growthree-six-events-2013.

27. ledynak, G., Galamandjuk, L., Dutchak, M., Balatska, L., Herasymchuk, A. \& Mazur, V. (2017). Effectiveness of Different Options when Teaching Children Basic Movements due to Certain Handedness. Journal of Physical Education and Sport, 17(2), 582-589. DOI:10.7752/jpes.2017.02088.

28. Inchley, J., Kirby, J., Currie, C. (2011). Longitudinal changes in physical selfperceptions and associations with physical activity during adolescence. Pediatric Exercise Science, 23(2), 237-249. DOI: https:// doi.org/10.1123/pes.23.2.237.

29. Mei-Dan, O., Carmont, M.R. (2013). Introduction. Adventure and extreme sports: Epidemiology, Treatment, Rehabilitation and Prevention. New-York Springer-Verlag, 1-5. DOI: https://doi. org/10.1007/978-1-4471-4363-5.

30. Reyna, V., Farley, F. (2006). Risk and rationality in adolescent decision making: Implications for theory, practice, and public policy. Psychological Science in the Public Interest, Sep.7(1), 1-44. DOI: https://doi.org/10.1111/j.1529-1006.2006.00026.x.

31. Van der Fels, Irene M.J., te Wierike, Sanne C.M., Hartman, E., Elferink, Marije T., Smith, J., Visscher, Cr. The relationship between motor skills and cognitive skills in 4-16 year old typically developing children: A systematic review. Journal of Science and Medicine in Sport, 18(6), 697-703. DOI: https://doi.org/10.1016/j.jsams.2014.09.007.

32. Willig, C.A. (2008). Phenomenological investigation of the experience of taking part in 'extreme sports'. J Health Psychol., 13(5), 690-702. DOI: https://doi.org/10.1177/1359105307082459.

33. Woodman, T., Hardy, L., Barlow, M., Le Scanff, C. (2010). Motives for participation in prolonged engagement high-risk sports: An agentic emotion regulation perspective. Psychology of Sport and Exercise, (11), 345-352. DOI: https://doi.org/10.1016/j.psychsport.2010.04.002. 